\title{
REHABILITASI HUTAN DAN LAHAN BERDASARKAN KEARIFAN LOKAL SUKU MOILE DAN SUKU MEYAH DI KABUPATEN MANOKWARI PROVINSI PAPUA BARAT \\ (Rehabilitation of Forest and Land Based On Local Knowledge of Moile and the Meyah in Manokwari Regency West Papua Province)
}

\author{
Mervin Arison Asmuruf ${ }^{1 *}$, Ris Hadi Purwanto ${ }^{2}$, dan Lies Rahayu Wijayanti Faida ${ }^{3}$ \\ ${ }^{1}$ Program Pascasarjana Ilmu Kehutanan, Fakultas Kehutanan, Universitas Gadjah Mada \\ Jl. Agro No.1, Bulaksumur, Sleman 55281. \\ ${ }^{2}$ Bagian Manajemen Hutan, Fakultas Kehutanan, Universitas Gadjah Mada \\ Jl. Agro No.1, Bulaksumur, Sleman 55281. \\ ${ }^{3}$ Bagian Konservasi Sumberdaya Hutan, Fakultas Kehutanan, Universitas Gadjah Mada \\ Jl. Agro No.1, Bulaksumur, Sleman 55281.
}

*Penulis korespondensi. Tel: 0274-550541. Email: mervinasmuruf@ gmail.com.

Diterima: 14 Maret 2017

Disetujui: 4 September 2017

\begin{abstract}
Abstrak
Kajian Rehabilitasi Hutan dan Lahan (RHL) di Kabupaten Manokwari Provinsi Papua Barat telah dilakukan dengan berdasarkan kearifan lokal Suku Moile dan Suku Meyah. Penelitian ini bertujuan untuk mengetahui jenis-jenis tanaman lokal, indentifikasi kearifan lokal masyarakat Suku Moile dan Suku Meyah dan merumuskan strategi RHL berdasarkan kearifan lokal masyarakat. Penelitian ini dilakukan di Kampung Sub Sai Distrik Warmare dan Kampung Lebau Distrik Manokwari Utara Kabupaten Manokwari Provinsi Papua Barat. Teknik pengambilan data adalah pendekatan metode kombinasi data primer dan sekunder yang diperoleh melalui observasi lapangan, wawancara dengan teknik Snowball sampling dan penelusuran dokumen. Metode deskriptif dengan analisis Miles dan Huberman digunakan untuk mengidentifikasi kearifan lokal Suku Moile dan Suku Meyah. Hasil penelitian menunjukkan bahwa jenis-jenis tanaman lokal yang berpotensi digunakan dalam kegiatan RHL di Kabupaten Manokwari adalah: tanaman yang mempunyai kualitas kayu pertukangan yang baik dan memiliki nilai ekonomis tinggi, seperti: kayu besi (Intsia bijuga), kayu susu (Astonia sp), kayu matoa (Pometia sp). Di samping tanaman yang buah dan kulitnya bernilai ekonomi tinggi sehingga dapat menambah penghasilan masyarakat, seperti: buah merah (Pandanus conoideus), Gaharu (Aquilaria malaccensis), Mangga (Manggifera indica), Rambutan (Nephelium lappaceum), Durian (Durio Zibethinus). Masyarakat Arfak pada kawasan ini memiliki nilai dan kearifan budaya Igya Ser Hanjob yang artinya berdiri menjaga batas. Kawasan hutan yang dimanfaatkan terbagi atas 4 (empat) bagian yakni Susti, Bahamti, Nimahamti dan Tumti, dengan fokus kegiatan RHL seharusnya dilakukan di Susti dan Nimahamti yang berfungsi sebagai kawasan penyangga.
\end{abstract}

Kata kunci: sawah kearifan lokal, rehabilitasi hutan dan lahan, hutan rakyat, kawasan lindung.

\begin{abstract}
Study of the Forest and Land Rehabilitation (FLR) in Manokwari Regency West Papua Province have been done based on local knowledge of Moile and the Meyah. This research aims to know the type of local plants, identification the local wisdom of a tribal society Moile and Tribe Meyah and formulate the FLR strategy based on the wisdom of the local community. The study is done in sub sai vilagge warmare district and lebau vilagge manokwari the northern district manokwari counties provincial west papua. Techniques used in the data is the approach combination method through observation field, interviews with snowball sampling techniques and the tracing documents. Descriptive method with an analysis Miles and Huberman used to identify local knowledge of Moile and Meyah. The results showed that the local-crop potentially used FLR in the district Manokwari intsia bijuga asltonia sp, pometia .sp, where its have good quality for use as timber carpentry having high as well as economic value and Pandanus conoideus, Aquilaria malaccensis, Manggifera indica, Nephelium lappaceum, Durio Zibethinus which fruit and the skin can be utilized to add community incomes. The community arfak in this area has a value and culture igya wisdom similar hanjob which means keeping the limit stood, forest areas being utilized divided over 4 (four) : susti, bahamti, nimahamti and tumti, where RHL activities should be undertaken in susti and nimahamti because it can function as buffer area.
\end{abstract}

Keywords: Local Knowledge, Rehabilitation of Forest and Land, forest.

\section{PENDAHULUAN}

Undang-Undang (UU) Nomor 41 Tahun 1999 tentang Kehutanan menyatakan bahwa hutan merupakan kekayaan alam yang dianugerahkan oleh Tuhan kepada bangsa Indonesia, merupakan kekayaan yang dikuasai oleh negara yang memberikan manfaat serbaguna bagi umat manusia. 
Hutan wajib dikelola dan dilestarikan sehingga dapat memberikan manfaat untuk sebesar-besar kemakmuran rakyat. Penyelenggaraan pengelolaan hutan yang bertujuan untuk sebesar-besar kemakmuran rakyat setidaknya dapat diindikasikan dengan peningkatan taraf kehidupan sosial ekonomi masyarakat desa hutan karena sumberdaya hutan sesungguhnya merupakan bagian yang tidak dapat dipisahkan dari kehidupan masyarakat.

Hutan sebagai suatu kesatuan ekosistem dalam kehidupan memberikan banyak manfaat terhadap kelangsungan hidup manusia dari jaman dulu sampai sekarang. Semua spesies baik flora maupun fauna yang berada di dalam hutan mempunyai nilai ekonomi bagi masyarakat setempat dan berpotensi menjadi gudang sumberdaya genetis bagi tanaman pertanian. Di samping itu, hutan dan masyarakat lokal memiliki hubungan dan interaksi yang bersifat sosio-kultural. Kedekatan masyarakat secara fisik dan emosional akan melahirkan pengetahuan mengenai hutan itu sendiri sehingga menciptakan kearifan tradisional. Kearifan tradisional yang merupakan modal sosial masyarakat lokal dapat digunakan sebagai landasan untuk pengelolaan sumberdaya hutan.

Masyarakat di sekitar hutan pada umumnya merupakan kelompok masyarakat yang relatif tertinggal ditinjau dari aspek sosial dan ekonominya dibandingkan dengan kelompok masyarakat di perkotaan (Nawir, 2008). Di Indonesia terdapat 48,8 juta orang yang tinggal pada lahan hutan negara, sekitar 10,2 juta di antaranya tergolong miskin. Selain itu ada sekitar 20 juta orang yang tinggal di desa-desa dekat hutan dan 6 juta orang di antaranya memperoleh sebagian besar penghidupannya dari hutan (Sunderlin dkk, 2005). Keberadaan masyarakat sekitar kawasan hutan merupakan komponen yang secara langsung berinterakasi dengan hutan yang berada di sekitarnya. Namun, jika interaksi yang dilakukan masyarakat merupakan tindakan yang dapat merusak alam maka keberadaan hutan akan terancam.

Masyarakat Arfak menempati wilayah kepala burung pulau Papua. Masyarakat Arfak juga disebut sebagai masyarakat suku besar Arfak karena terdiri dari beberapa sub suku yakni suku Hatam, Moile, Sough dan Meyah. Masyarakat Arfak memiliki pola hidup yang bergantung pada lingkungan alam, terutama dalam hal pemanfaatan hasil hutan. Hutan bagi suku Arfak merupakan tempat memperoleh bahan makanan, obat-batan, bahan bangunan (rumah/kandang), dan memiliki nilai mistik. Suku Arfak memahami hutan selain memiliki fungsi ekonomi, ekologi juga memiliki fungsi sosial budaya (Ullo, 2013). Keberadaan masyarakat lokal yaitu Suku Moile dan Suku Meyah di Kabupaten
Manokwari Provinsi Papua Barat memiliki ketergantungan terhadap sumberdaya hutan yang berupa manfaat lahan untuk pertanian, sumber kayu dan sumber air untuk kedua kelompok masyarakat. Kedua kelompok masyarakat ini memanfaatkan sumberdaya hutan untuk pemenuhan kebutuhan hidup sehari-hari dan penambahan penghasilan.

Berdasarkan hasil peninjauan kembali data lahan kritis, total luas lahan kritis di Indonesia sebesar 82,1 juta $\mathrm{Ha}$, dengan rincian luas lahan sangat kritis dan kritis adalah 29,9 juta $\mathrm{Ha}$, sedangkan luas lahan agak kritis 52,2 juta Ha. Lahan sangat kritis dan kritis seluas 29,9 juta Ha, dan ini perlu menjadi sasaran indikatif Rehabilitasi Hutan dan Lahan (RHL) untuk diprioritaskan. Sementara itu Kementerian Kehutanan sejak tahun 2010 menetapkan program peningkatan fungsi dan daya dukung DAS berbasis pemberdayaan masyarakat pada 108 DAS prioritas (Walangitan, 2014). Pemerintah telah melakukan berbagai upaya untuk mengurangi laju lahan kritis di antaranya adalah melalui kegiatan RHL yang programprogram di dalamnya meliputi antara lain : hutan desa (HD), hutan tanaman rakyat (HTR), hutan kemasyarakatan $(\mathrm{HKm})$ dan program kebun bibit rakyat(KBR). KBR merupakan program pemerintah untuk menyediakan bibit tanaman hutan dan jenis tanaman serbaguna (MPTS) yang dilaksanakan secara swakelola oleh kelompok masyarakat, terutama di pedesaan (Permenhut no 17 tahun 2012).

Degradasi sumberdaya hutan dan lahan yang cukup besar berdampak terjadinya bencana alam banjir dan tanah longsor pada musim penghujan dan kekeringan yang semakin luas dan panjang pada musim kemarau. Melihat kondisi dan fenomena alam yang terjadi pada beberapa tahun terakhir, maka perlu segera dilakukan upaya-upaya perbaikan dan pemulihan kawasan hutan dan lahan kritis melalui upaya rehabilitasi hutan dan lahan.

RHL merupakan suatu upaya untuk memulihkan, mempertahankan dan meningkatkan fungsi hutan dan lahan sehingga daya dukung, produktivitas dan peranannya dalam mendukung sistem penyangga kehidupan tetap terjaga. Upaya tersebut dilakukan untuk meningkatkan fungsi hutan baik pada hutan negara maupun hutan milik sehingga dapat memberikan manfaat ekonomi, ekologi dan sosial secara seimbang. Kegiatan RHL dilakukan dengan menanam jenis tanaman berdasarkan kelas kesesuaian lahan yang dapat melindungan tanah serta memperbaiki kesuburan sehingga dapat mengambalikan fungsi hutan sebagaimana mestinya.

Pengembangan RHL di Wilayah Provinsi Papua Barat merupakan upaya yang baik bagi pelestarian fungsi hutan dan lahan di Provinsi 
Papua Barat (Petocz, 1987). Hal ini tentunya tidak terlepas dari aspek persiapan bibit tanaman RHL maupun masyarakat pelaksana kegiatan di lapangan, sehingga diperlukan perencanaan dan koordinasi yang baik antar semua pihak yang terlibat, baik provinsi maupun kabupaten dalam pelaksanaan kegiatan dimaksud. Namun pada kenyataannya kegiatan RHL ini tidak melibatkan masyarakat pemilik hak ulayat baik dalam pemilihan jenis tanaman lokal maupun pada tahapan perencanaan, pelaksanaan dan evaluasi kegiatan RHL tersebut. Sebagai contoh Masyarakat Suku Moile dan Suku Meyah di Kabupaten Manokwari tidak dilibatkan dalam kegiatan RHL, sehingga hal ini sangat berdampak pada tingkat keberhasilan program RHL pada Kabupaten/ Kota di Provinsi Papua Barat.

Kearifan lokal masyarakat Suku Moile dan Suku Meyah terhadap program rehabilitasi hutan dan lahan di Provinsi Papua Barat perlu dikaji untuk dapat melihat dan mengetahui sejauh mana peran masyarakat setempat dalam pelaksanaan rehabilitasi hutan dan lahan untuk mensejahterakan masyarakat. Penelitian ini bertujuan untuk (i) mengetahui jenis - jenis tanaman lokal yang berpotensi untuk digunakan dalam program RHL di Kabupaten Manokwari Provinsi Papua Barat (ii) Mengetahui kearifan lokal masyarakat Suku Moile dan Suku Meyah di Kabupaten Manokwari yang dapat mendukung program RHL serta (iii) merumuskan strategi RHL berdasarkan kearifan lokal masyarakat Suku Moile dan Suku Meyah di Kabupaten Manokwari.

\section{METODE PENELITIAN}

\section{Waktu dan Lokasi}

Kegiatan penelitian dilaksanakan pada bulan Februari-September 2016. Penelitian ini dilaksanakan di Kabupaten Manokwari Provinsi Papua Barat pada Kampung Sub Sai Distrik Warmare (Suku Moile) dan Kampung Lebauw Distrik Manokwari Utara (Suku Meyah). Pemilihan lokasi penelitian berdasarkan Pengembangan Program Rehabilitasi Hutan dan Lahan di Kabupaten Manokwari, dengan pertimbangan, bahwa belum ada kajian kearifan lokal masyarakat terhadap kegiatan RHL dan strategi RHL.

\section{Bahan dan Alat}

Peralatan yang digunakan dalam penelitian ini adalah sebagai berikut: alat tulis, alat perekam, kuisioner, kamera dan software AHP Expert Choice untuk membantu mendapatkan bobot dari matriks perbandingan berpasangan pada metode AHP.

\section{Prosedur \\ Metode Pengumpulan Data}

Jenis data dan informasi yang dikumpulkan dalam penelitian ini terdiri dari data primer dan sekunder, yakni sebagai berikut : Data primer, merupakan data atau informasi yang diperoleh langsung dengan observasi lapangan dan informasi melalui wawancara. Informasi yang dibutuhkan mencakup pengetahuan informan, kearifan lokal masyarakat, jenis-jenis tanaman lokal dan pemanfaatannya. Teknik yang digunakan dalam pengumpulan data yakni melalui observasi lapangan, wawancara dengan teknik Snowball sampling dan penelusuran dokumen. Dalam menetapkan informan menggunakan teknik snowball sampling. Snowball sampling merupakan teknik pengambilan sampel dengan bantuan keyinforman dan dari key informan inilah akan berkembang sesuai petunjuk.

\section{Analisis Data}

Masalah berikut yakni merumuskan strategi rehabilitasi hutan dan lahan berdasarkan kearifan lokal masyarakat yang berkelanjutan ditentukan dengan mengevaluasi faktor-faktor internal dan eksternal terkait dengan pemanfaatan hutan yang dilakukan oleh masyarakat. Faktor-faktor tersebut diperoleh melalui wawancara mendalam dengan masyarakat lokal sebagai informan dan informan yang dianggap mengetahui serta memahami program RHL di Kabupaten Manokwari.

Diharapkan melalui metode tersebut dapat memberikan gambaran mengenai kondisi sumberdaya hutan, masyarakat lokal dan strategi RHL berdasarkan kearifan lokal masyarakat. Data diolah secara deskriptif sehingga dengan mengetahui hal ini diharapkan dapat dirumuskan alternatif strategi rehabilitasi hutan yang tepat dan berkelanjutan yang mencakup peran serta masyarakat, kelembagaan, dan regulasi. Pada akhirnya hasil analisis yang dilakukan diharapkan dapat memberi suatu gambaran kesimpulan dan rekomendasi kepada pihak terkait dalam menentukan teknik pendekatan pengembangan masyarakat di lokasi/kampung tersebut.

\section{HASIL DAN PEMBAHASAN}

\section{Jenis Tanaman Lokal Dalam Program RHL}

Tekanan terhadap SDH sangat mengkhawatirkan. Saat ini terdapat kawasan hutan dan lahan rusak sekitar 43 juta Ha dengan laju 1,6 juta $\mathrm{Ha} /$ tahun dan cenderung meningkat setiap tahun. Kerusakan SDH dan lahan berdampak negatif terhadap mutu lingkungan (global), kehidupan masyarakat, hilangnya biodiversity dan pendapatan negara serta mengancam kehidupan berbangsa. Upaya penanggulangan kerusakan hutan 
dan lahan telah dilaksanakan melalui berbagai program, namun belum sebanding dengan laju kerusakan yang terjadi. Kegiatan tersebut umumnya bersifat top down planning dan memiliki banyak kelemahan. Pada saat ini Kementerian Kehutanan telah meletakkan kegiatan pembangunan hutan tanaman sebagai salah satu kebijakan prioritas disamping empat kebijakan prioritas lainnya. Perencanaan pelaksanaan kebijakan tersebut perlu dipersiapkan dengan baik.

Hal ini disambut baik oleh masyarakat Provinsi Papua Barat terlebih khusus masyarakat Suku Moile dan Suku Meyah di Kabupaten Manokwari karena masyarakat setempat dapat menyesuaikan jenis-jenis tanaman yang sesuai dengan kemampuan lahan maupun setidaknya dapat berperan dalam peningkatan sumber daya hutan dan ekonomi masyarakat setempat, meskipun pada kenyataannya tidak seperti yang diharapkan. Hal ini seperti tergambar pada Tabel 1 .

Menurut Hastanti dan Yeny (2009), kawasan ini mengandung potensi keanekaragaman hayati yang tinggi, baik flora maupun fauna. Menurut jenis tanamannya, kawasan hutan di Manokwari merupakan tipe hutan heterogen. Jenis flora yang tumbuh antara lain kayu besi (Intsia bijuga), kayu susu (Alstonia sp), kayu binuang (Octomeles sumatrana Miq), kayu matoa (Pometia .sp), kayu nyatoh (Palaquium sp), Macaranga sp, buah merah (Pandanus conoideus).

Tabel 1 menunjukkan bahwa jenis tanaman yang digunakan dalam kegiatan RHL di Kabupaten Manokwari yakni Dinas Kehutanan Provinsi Papua Barat ada 2 jenis yakni matoa kelapa dan gaharu sedangkan Dinas Kehutanan Kabupaten Manokwari ada 6 jenis yakni kayu besi, matoa kelapa, coklat, mangga, rambutan dan glodokan serta yang dikembangkan masyarakat secara tradisional ada 3 jenis yakni mangga, rambutan dan durian. Mangga, rambutan dan durian merupakan jenis tanaman lokal yang telah dikembangkan secara turuntemurun oleh masyarakat Suku Moile dan Suku Meyah. Tanaman yang dikembangkan secara tradisional oleh masyarakat Suku Moile dan Suku Meyah yakni tanaman - tanaman yang setidaknya dapat dikonsumsi dan dijual guna meningkatkan ekonomi keluarga. Pengertian tanaman lokal merujuk bahwa yakni tanaman yang telah dikembangkan dan dimanfaatkan oleh masyarakat lokal secara turun-temurun baik sebagai tanaman pertanian (buah-buahan) maupun tanaman yang dapat dimanfaatkan hasil kayunya, namun yang sering dibudidayakan oleh masyarakat setempat yakni tanaman buah-buahan seperti pada Tabel 1 .

Jenis-jenis tanaman lokal yang berpotensi digunakan dalam kegiatan RHL di Kabupaten Manokwari yakni kayu besi (Intsia bijuga), kayu susu (Astonia sp), kayu matoa (Pometia .sp) dimana kayunya mempunyai kualitas baik untuk digunakan sebagai kayu pertukangan yang memiliki nilai ekonomis tinggi serta buah merah (Pandanus conoideus), Gaharu (Aquilaria malaccensis), Mangga (Manggifera indica), Rambutan (Nephelium lappaceum), Durian (Durio Zibethinus) yang buah dan kulitnya dapat dimanfaatkan untuk menambah penghasilan masyarakat.

Tanaman-tanaman yang ditawarkan oleh pemerintah baik Pemerintah Provinsi Papua Barat maupun Pemerintah Kabupaten Manokwari sebagian jenis tanaman tidak sesuai dengan yang dibutuhkan atau yang sedang dikembangkan secara tradisional dan turun temurun oleh masyarakat Suku Moile dan Suku Meyah serta dari tanaman yang ditanam tidak ada perawatan dari pemerintah dikarenakan masyarakat tidak dilibatkan dalam kegiatan rehabilitasi hutan dan lahan dimaksud. Hal ini merupakan salah satu penyebab tidak berhasilnya kegiatan rehabilitasi hutan dan lahan di Kabupaten Manokwari.

Tabel 1. Jenis tanaman kegiatan RHL di Kabupaten Manokwari

\begin{tabular}{lccc}
\hline \multicolumn{1}{c}{ Stakeholders } & Jenis tanaman & Nama latin & Luas (Ha) \\
\hline 1. Dinas Kehutanan Prov. Papua & Matoa kelapa & Pometia pinnata & 10 \\
Barat & Gaharu & Aquilaria malaccensis & 2 \\
& Kayu besi & Intsia bijuga & 4 \\
& Matoa kelapa & Pometia pinnata & 4 \\
2. Dinas Kehutanan Kab. & Coklat & Theobroma cacao L. & 5 \\
Manokwari & Mangga & Mangifera indica & 2 \\
& Rambutan & Nephelium lappaceum & 2 \\
& Glodokan & Polyalthia longifolia & 5 \\
3. Masyarakat & Mangga & Mangifera indica & 4 \\
& Rambutan & Nephelium lappaceum & 4 \\
\hline
\end{tabular}

Sumber : Badan Pusat Statistik Kabupaten Manokwari. (2015) 


\section{Kearifan Lokal Masyarakat Suku Moile dan Suku Meyah}

Adat istiadat dalam kehidupan masyarakat suku Moile dan suku Meyah masih sangat kuat dan hidup dalam masyarakat hingga sekarang. Mereka hidup secara kekerabatan, sistem pemerintahan adat masyarakat suku Moile dan suku Meyah tidak dikenal adanya kepala suku besar, namun pada masyarakat suku Moile dan suku Meyah dikenal dengan sebutan kinamnya. Kepemimpinan di masing-masing kinam terdiri dari 4 (Ullo, 2013) pola kepemimpinan masyarakat di kawasan kepala burung antara lain:

1. Andigpoi adalah pemegang kekuasaan tertinggi dimasyarakat dan membuat kebijakankebijakan, mengambil keputusan serta bertanggung jawab atas segala resiko yang timbul dari keputusan tersebut

2. Pinjoindig adalah perpanjangan tangan dari andigpoi yang ruang lingkup kewenanganya tidak melebihi andigpoi.

3. Pinjoi pilei adalah pelaksanaan perintah secara langsung di masyarakat.

4. Nikei adalah hakim yang membantu andigpoi dalam hal menyelesaikan masalah social di masyarakat antara lain bayar denda dan sengketa adat lainnya. Keanggotaan nikei dipilih dari andigpoi atau pinjoindig dengan beberapa kriteria, antara lain memiliki sikap adil (tidak memihak) dan berpengalaman, bijaksana,dan tidak emosional dalam menyelesaikan permasalahan di masyarakat.

Suku Moile dan Suku Meyah yang tinggal di kawasan Suku Besar Arfak dan hidup secara tradisional dengan ketergantungan kuat pada hutan dalam pemenuhan kebutuhan sehari-hari. Hutan baginya merupakan tempat memperoleh bahan makanan, obat-obatan, bahan bangunan (rumah/kandang), dan memiliki nilai mistik. Dapat dikatakan hutan memiliki fungsi sosial budaya dalam kehidupan mereka.

Cara pemanfaatan hutan yang telah berusia tua tersebut pada gilirannya menjadi kearifan lokal dalam memanfaatkan hutan. Kearifan ini hidup dan menyatu dengan kebudayaan mereka, terus terpelihara bersama aturan-aturan yang dikenal dengan adat istiadat, norma masyarakat, dan berbagai pantangan yang pada dasarnya untuk menjaga keselarasan agar hutan tetap lestari. Suku Moile dan Meyah hingga sekarang masih meneruskan aktivitas itu dalam kehidupannya, menunjukan suatu keberhasilan hidup bersama dengan hutan dalam waktu yang sangat panjang atau dapat dikatakan lestari. Hal ini juga serupa dengan diuraikan oleh Paembonan (2015) untuk pemanfaatan hutan lindung di Pegunungan Bintang, serta oleh Jatmiko dkk (2012) di pegunungan kawasan Wonosobo Jawa Tengah.

Seperti diacu dari Barumbun (2009), masyarakat di Suku Besar Arfak pada umumnya termasuk suku Moile dan Meyah sudah memiliki aturan adat untuk mengelola hutan yang dikenal dengan nama Ig ya ser hanjob (dalam bahasa Hatam / Moile) atau Mastogow hanjob (dalam bahasa Soughb). Ig ya dalam bahasa hatam berarti berdiri, ser artinya menjaga dan hanjob berarti batas. Secara harfiah Ig ya ser hanjob mengandung makna berdiri menjaga batas, namun batas disini bukan hanya bermakna sebagai suatu kawasan, namun secara luas bermakna mencakup segala aspek kehidupan masyarakat Arfak. Kearifan suku Moile dan Meyah menjelaskan bahwa aspek biofisik, ekonomi dan sosial budaya menjadi pijakan kegiatan berburu, berladang, meramu dan pemanfaatan kayu. Dalam semangat Ig ya ser hanjob suku Moile dan Meyah melakukannya untuk kelangsungan hidup dengan tetap memperhatikan kelestarian bukan eksploitasi dan kapitalisme.

Dalam bahasa Moile, Igya ser hanjob juga berarti mastogow hanjob. Konsep ini dari sisi konservasi didasarkan pada filosofi masyarakat yang menganggap hutan sebagai ibu yang memberikan air susu untuk anaknya, sehingga melalui filosofi inilah maka masyarakat berusaha menjaga hutan agar sumber dayanya dapat dirasakan manfaatnya sampai generasi selanjutnya

Menurut Ullo (2013), adat istiadat suku Moile dan suku Meyah mengandung kearifan dalam memanfaatkan hutan, secara prinsip dalam keraifannya mengatur agar pemanfaatan hutan tidak dilakukan secara eksploitatif. Prinsip ini dalam adat mereka dikenal dengan Ig ya ser hanjob, yang berarti melakukan pemanfaatan hutan untuk kelangsungan hidup dengan tetap memperhatikan kelestarian. Sebagai perwujudan Ig ya ser hanjob, berladang dilakukan dengan memanfaatkan lahan pertanian yang sudah ditanami. Berburu (Ntteisi) dilakukan untuk memenuhi kebutuhan protein hewani (konsumsi), tidak untuk di komersilkan. Meramu dilakukan untuk mengumpulkan makanan dari dalam hutan dan tumbuhan obat untuk kesehatan. Dan pemanfaatan kayu dilakukan untuk memenuhi bahan bangunan, peralatan berladang, peralatan berburu, dan peralatan rumah tangga.

Di wilayah Manokwari dan pegunungan Arfak, kawasan hutan yang dimanfaatkan oleh masyarakat terbagi atas 4 (empat) bagian yakni Susti, Bahamti, Nimahamti dan Tumti (Salosa dkk., 2011). Susti adalah kawasan yang diusahakan oleh masyarakat baik untuk tempat tinggal maupun untuk berkebun. Nimahamti adalah kawasan hutan 
yang dapat dimasuki untuk mengambil kayu dengan persetujuan kepala suku. Bahamti adalah kawasan hutan yang berlumut dan terdapat di wilayah yang sangat curam, sedangkan tumti adalah bagian puncak gunung. Susti dan Nimahamti dapat difungsikan sebagai kawasan penyangga jadi pemanfaatan hutan hanya bisa dilakukan pada Susti dan Nimahamti. Namun kondisi dan keberadaan areal ini sudah berada di wilayah yang sangat terjal.

\section{Hubungan Antara Kearifan Lokal dan Kegiatan RHL}

Dari penjelasan sebelumnya dapat dilihat bahwa selain kearifan lokal igya ser hanjob yang secara turun temurun tumbuh dan berkembang dikalangan masyarakat Suku Moile dan Suku Meyah, nilai-nilai kearifan lokal igya ser hanjob juga dapat terlihat dalam pola pengelolaan sumber daya alam di mana sering dikenal dengan Bahamti, Tumti, Nimahamti dan Susti. Di sisi lain pelaksanaan dan pengembangan kegiatan rehabilitasi hutan lahan di Kabupaten Manokwari tidak sesuai dengan yang diinginkan oleh masyarakat. Dalam pelaksanaan kegiatan yakni Pemerintah Daerah dalam hal ini Dinas Kehutanan tidak melibatkan masyarakat dalam perencanaan kegiatan rehabilitasi hutan dan lahan. Pelaksanaannya juga diserahkan kepada pihak ketiga dengan perjanjian kontrak, di mana untuk luas dan lokasi pelaksanaan kegiatan dimaksud sudah ditentukan tanpa melibatkan masyarakat. Di beberapa lokasi, kegiatan ini sudah dikelola oleh masyarakat pemilik hak ulayat yang mempunyai badan usaha tetapi masih dengan perjanjian kontrak, namun dalam pelaksanaannya dilapangan belum tepat sasaran karena lokasi tanam yang tidak sesuai yakni pada kawasan Bahamti dan Tumti yang mengalami kerusakan akibat longsor tetapi dapat dipulihkan dengan suksesi primer yang membutuhkan tidak lama serta dalam perawatannya agak sulit karena keadaan lokasi yang sulit untuk dijangkau. Hal-hal seperti yang telah dikemukakan ini, sudah barang tentu akan mempengaruhi pelaksanaan kegiatan rehabilitasi hutan dan lahan karena dari tingkat keberhasilan tumbuh tanaman relatif kecil dikarenakan sulitnya akses ke lokasi sehingga tidak adanya perawatan oleh masyarakat.

Dari keterangan tersebut zona kawasan sumber daya alam masyarakat Suku Moile dan Suku Meyah yang dapat mendukung kegiatan rehabilitasi hutan dan lahan yakni pada zona kawasan Nimahamti dan Susti, namun pada kenyataannya kegiatan rehabilitasi hutan dan lahan di Kabupaten Manokwari tidak dilakukan pada kedua kawasan ini. Hal ini dikarenakan lokasi penanaman pada kegiatan rehabilitasi hutan dan lahan telah ditentukan langsung oleh pemerintah dengan tidak melibatkan masyarakat setempat, keadaan ini terjadi sehingga dalam pelaksanaan kegiatan menjadi tidak tepat sasaran dan akan berdampak sangat kecil terhadap peurunan lahan kritis. Keadaan ini merupakan salah satu penyebab ketidak berhasilannya kegiatan reahabilitasi hutan dan lahan di Kabupaten Manokwari.

\section{KESIMPULAN}

Berdasarkan Jenis-jenis tanaman lokal yang berpotensi digunakan dalam kegiatan RHL di Kabupaten Manokwari yakni kayu besi (Intsia bijuga), kayu susu (Asltonia sp), kayu matoa (Pometia .sp) dimana kayunya mempunyai kualitas baik untuk digunakan sebagai kayu pertukangan yang memiliki nilai ekonomis tinggi serta buah merah (Pandanus conoideus), Gaharu (Aquilaria malaccensis), Mangga (Manggifera indica), Rambutan (Nephelium lappaceum), Durian (Durio Zibethinus) yang buah dan kulitnya dapat dimanfaatkan untuk menambah penghasilan masyarakat.

Masyarakat Arfak terutama yang bermukim pada kawasan ini memiliki nilai dan kearifan budaya Igya Ser Hanjob yang artinya berdiri menjaga batas. Pada masyarakat Suku besar Arfak dikenal Bahamti yaitu wilayah hutan primer yang tak boleh diganggu sama sekali (wilayah perlindungan alam), kemudian Nimahamti yakni wilayah yang boleh diambil hasil hutannya namun dalam jumlah yang terbatas, serta Susti yang merupakan kawasan pemanfaatan baik untuk berkebun maupun sebagai wilayah pemukiman, tumti adalah bagian puncak gunung. Kegiatan RHL seharusnya dilakukan di Susti dan Nimahamti karena dapat difungsikan sebagai kawasan penyangga jadi pemanfaatan hutan hanya bisa dilakukan pada susti dan nimahamti.

\section{DAFTAR PUSTAKA}

Badan Pusat Statistik Kabupaten Manokwari, 2015. Kabupaten Manokwari Dalam Angka. Badan Pusat Statistik Kabupaten Manokwari.

Hastanti, B.W. dan Yeny, I., 2009. Strategi Pengelolaan Cagar Alam Pegunungan Arfak Menurut Kearifan Lokal Masyarakat Arfak Di Manokwari Papua Barat. Info Sosial Ekonomi, 9(1):19-36.

Jatmiko, A., Sadono, R., dan Rahayu W.P.L., 2012. Evaluasi Kegiatan Rehabilitasi Hutan dan Lahan Menggunakan Analisis Multikriteria (Studi Kasus di Desa Butuh Kidul Kecamatan 
Kalikajar, Kabupaten Wonosobo, Jawa Tengah). Jurnal Ilmu Kehutanan, 6(1):30-44.

Nawir, A.A., 2008. Rehabilitasi Hutan di Indonesia:

Akan Kemanakah Arahnya Setelah Lebih dari

Tiga Dasawarsa? Bogor: Center for International Forestry Research (CIFOR).

Paembonan, J., 2015. Pola Akses Masyarakat Lokal

Dalam Pemanfaatan Hutan Lindung Di

Kabupaten Pegunungan Bintang. Tesis.

Program Pascasarjana Ilmu Kehutanan,

Fakultas Kehutanan. Universitas Gadjah Mada. Yogyakarta.

Petocz, R., 1987. Konservasi Alam dan Pembangunan Irian Jaya. Jakarta: PT. Gramedia.

Salosa, S.T., Awang, S.A., Suryanto, P., dan Purwanto, R.H., 2014. Hutan Dalam Kehidupan Masyarakat Hatam Di Lingkungan Cagar Alam Pegunungan Arfak. J. Manusia \& Lingkungan, 21(3):349-355.
Sunderlin, W.D., Angelsen, A., Belcher, B., Burgers, P., Nasi, R., Santoso, L., dan Wunder, S., 2005. Livelihoods, Forest and Conservation in Developing Countries: An Overview. World Development, 33(9):1383-1402

Barumbun, T.P., 2009. Kearifan Budaya Arfak Ighya Ser Hanjob, Berdiri Jaga Batas. Website: http://pongpalita.blogspot.co.id/ 2009/07/kearifan-budaya-arfak_01.html

(Diakses Januari 2016)

Ullo, F., 2013. Studi Pengelolaan Sumber Daya Alam dan Lingkungan Berbasis Kearifan Lokal Masyarakat: Kasus Cagar Alam Pegunungan Arfak, Kabupaten Manokwari Papua Barat. Tesis. Fakultas Kehutanan Universitas Gadjah Mada.

Walanggitan, H., 2014. Perencanaan Rehabilitasi Hutan Dan Lahan (Rhl) Berbasis Kemampuan Lahan Di Daerah Tangkapan Air (Dta) Danau Tondano. Jurnal Wasian, 1(2):45-56. 